
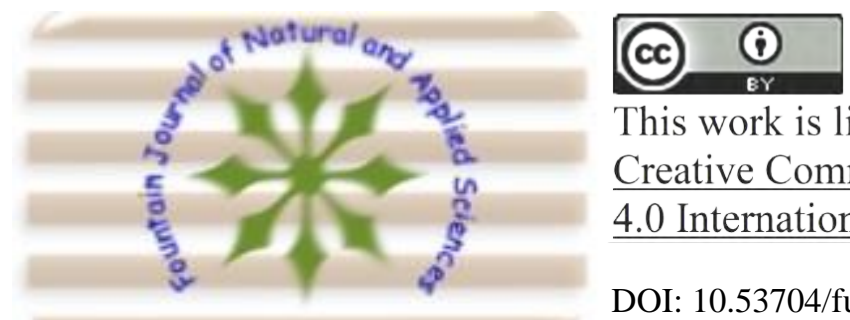

This work is licensed under

Creative Commons Attribution

4.0 International License.

DOI: $10.53704 /$ fujnas.v8i2.230

A publication of College of Natural and Applied Sciences, Fountain University, Osogbo, Nigeria.

Journal homepage: www.fountainjournals.com

ISSN: 2354-337X(Online),2350-1863(Print)

\title{
2D Resistivity Tomography Survey for Leachate Plume from Isundunrin Poultry Disposal Pits
}

*Fakunle, M. A., Alabi, O. O., Olatona, G. I., Oladejo, O. F. and Adeleke, J. T.

Department of Physics, Osun State University, Osogbo, Nigeria

\begin{abstract}
Management of dead birds in poultry farms has been a major problem in Nigeria. This study aimed at using 2D resistivity tomography to outline leachate plume from disposal pits in a poultry farm. 2D electrical resistivity tomography were conducted along three profiles, two of which were $3.0 \mathrm{~m}$ and 25.0 $\mathrm{m}$ respectively to the two available mortality pits (Pit1 and Pit 2) while the third was $300.0 \mathrm{~m}$ away from the mortality Pit 1. Profile length of $100.0 \mathrm{~m}$ each and interspaced $5.0 \mathrm{~m}$ oriented in the North-East (Profile 1), South-East (Profile 2) and North-East (Profile 3) directions respectively was covered. 2D resistivity data inversions were performed on the obtained converted apparent resistivity using DIPROWIN software. Five water samples collected from five different hand dug wells available within the poultry farm were analysed for hydro chemical parameters. 2D results showed conductive paths occurrence in transverse one at the depth of $5.0 \mathrm{~m}$, a horizontal distance of $45.0 \mathrm{~m}$ to $55.0 \mathrm{~m}$, and had migrated down to the depth of $10.0 \mathrm{~m}$. The second traverse showed varying resistivity values ranged $7.0 \Omega \mathrm{m}$ to $31.0 \Omega \mathrm{m}$ up to a depth of $15.0 \mathrm{~m}$, an indication of the presence of clay soil. Low resistivity values ranged $14.0 \Omega \mathrm{m}$ to $49.0 \Omega \mathrm{m}$ were recorded in traverse 3. The extent of the contaminant is prominent at the topmost part of the soil and to almost $10.0 \mathrm{~m}$ depth. This was attributable to the contaminant from the deposit site of faeces of the poultry. Hydro chemical analysis indicated high values of Conductivity and Total Dissolved Solids (TDS). This confirms the migration of leachate from the disposal pits to the surrounding soils and groundwater and the 2D results obtained from disposal Pit 1. Other alternative methods of disposing dead birds are hereby recommended.
\end{abstract}

Keywords: Contamination; dead birds' mortality pits; profile length; 2D resistivity tomography

\section{Introduction}

In Nigeria poultry, livestock and dairy industries are on the increase in order to meet the growing demand of animal protein resulting from increase in population and to meet the supply of inexpensive and safe meat and eggs (FAO, 2006). However, the growth of this industry has its own challenges as with other industry. These challenges include odour emission, which comes from fresh and decomposing waste products such as manure, feather, bedding / litters and how to handle farm mortalities of birds on a daily basis (Kolominskas

*Corresponding author: +2347035354450

Email address: mutiu.fakunle@uniosun.edu.ng 
et al., 2002, Ferket et al., 2002). The death loss in any poultry industries is inevitable and an unfortunate reality that requires appropriate and special handling to prevent the spread of disease, odour that are usually associated with bird mortality and pest problems, and the possible contamination of surface and groundwater. The death could be because of the attack of pathogens that have the potential to infect and produce disease and the inability to cope with the stress that birds were exposed to. The poultry, livestock and dairy practice is to confine these animals or to rear them as free range. This study focuses on confined poultry animals where layers were kept for egg productions. Ritter et al. (1988) examined the impact of dead birds' disposal on groundwater quality, detected that 3 percent $(3 \%)$ of 25,000 broilers died during a six week growing period in Delaware Georgia and 2,000 pounds of carcass were produced. Ritter and Chirnside (1995) also reported that 4 - 5 percent mortality rates of broiler were recorded in Delmarva Peninsula Canada. Disposal of these magnitudes of dead birds' immediately is of utmost importance to prevent the spread of diseases associated with dead birds. A convenient, practical, effective and rapid methods need to be employed and developed for in situ disposal to have a healthy environment. The management of these dead birds has been a major problem in Nigeria and other developing countries as well. Disposal methods (practices) that are being used in developed and developing countries in the past and today include burial pit, landfills, compositing, incineration, rendering. The study carried out by UNDP (2006) in Nigeria found out that, there are no particular method adhered to and that in some villages carcasses were thrown randomly into nearby bushes or open dumpsites. In addition, if pits were dug, there was no adherence to any standard with regard to the location or the depth of the pits dug for the burial of the carcasses. Factors such as environmental requirements, management procedures, cost and convenience need to be considered in the choice of the method and that they varied from one method to another (Myers et.al; 1999). In many developed and developing countries, Burial pits are used to disposed off large dead birds because of its convenience and simplicity. These burial pits are made up of old metal feed bins whose bottom have being cut out and invariably will have contact with the soil. In this work an abandon hand dug wells without water were converted to poultry mortality pits. These pits were not lined at the bottom and sideways. The depth of these mortality pits were very close to the water table when compared with the available hand dug wells where static water level is $9.0 \mathrm{~m}$ deep each in the farm. These disposed dead birds inside these pits, undergo decomposition process to release nutrients, pathogen and other components of the animals into the surrounding environment. During decomposition the mortalities were transformed, lost to air or may be immobilized so that they pose no environmental threat. The products of decomposition are organic liquid (leachate) and obnoxious gases. Large volumes of these carcasses can generate excessive amounts of leachate and other pollutants such as Ammonia $\left(\mathrm{NH}_{3}\right)$, volatile organic compounds and hydrogen sulphide $\left(\mathrm{H}_{2} \mathrm{~S}\right)$ thereby increasing the environmental pollution (Gerber et al., 2008). The leachate could contain nitrates, microbes and other potential water contaminants. The presence of nitrate indicates possible bacterial contamination. Nitrate and Ammonia is the end - product of aerobic and biological decomposition of organic nitrogenous matter. When this ammonia is present in water, react to form ammonium $\left(\mathrm{NH}_{4}{ }^{+}\right)$and hydroxyl $\left(\mathrm{OH}^{-}\right)$ions and thereby increases the $\mathrm{pH}$. The liquid leachate may infiltrate the soil and groundwater to contaminate them (Freedman and Fleming, 2003). Various researchers such as Jegede et al., (2011), Ogungbe et al., (2012), Okpoli et al., (2013) and Ganiyu et al., (2015) had successfully delineated leachate plume migration in different landfill sites found in towns. So, 2D electrical resistivity tomography is used in this study, because the resistivity of rocks is strongly influenced by the presence of groundwater, which acts as an electrolyte. The conductivity of the groundwater is greatly influenced by the presence of both cation and anion of the leachate in the groundwater since the minerals that form the matrix of a rock are generally poorer conductors than groundwater. The ions (cations and anions) produced by decaying dead birds greatly influence the conductivity of 
groundwater. Previous studies have shown elevated groundwater ammonia and nitrate levels near disposal pits (Ritter and Chirnside 1995; Hatzell, 1995) which contributed to the conductivity of the groundwater. Therefore this work aimed at investigating effect of poultry mortality pits on farm groundwater by employing 2D electrical resistivity imaging in order to delineate the leachate plumes and the main objective is to relate any groundwater contamination to poultry mortality disposal inside pits and the farm.

\section{Description of the Study Site}

The study site, an active poultry farm in which the mortality pits (figure 1) are located, is in Isundunrin and is just $2.0 \mathrm{~km}$ from the middle of the town. It is easily accessible from Ejigbo by major tarred roads, minor un- tarred roads and footpaths in Ejigbo Local Government Area of Osun State, South Western Nigeria. The farm lies within longitude E04 $16^{\prime} 34^{\prime \prime}-\mathrm{E} 04^{\circ} 15^{\prime} 46^{\prime \prime}$ and latitude N07 ${ }^{\circ}$ 51 $^{\prime}$ $32^{\prime \prime}-\mathrm{N} 07^{\circ} 51^{\prime} 52^{\prime \prime}$. The study site lies within the tropical region of Africa and the climate condition is characterised by alternating wet and dry seasons. The wet season is characterised by heavy rainfall that starts in March and ends in October while the dry season is from November to February. The mean annual rainfalls are $150.0 \mathrm{~cm}$, and mean annual relative humidity is above $80 \%$ while the mean annual temperature is about $28^{\circ} \mathrm{C}$. The vegetation of the study area resembles that of the South Western Nigeria, which is evergreen. Around the study site are residential buildings which makes the sparse while away from it are thicker vegetation. The environs of the location site are well drained with much drainage exhibiting dendrites patterns. Many of the rivers and streams are structurally controlled which favoured the growth of many wet lands around the underlying site. Figure 2 is the location map of the study site.

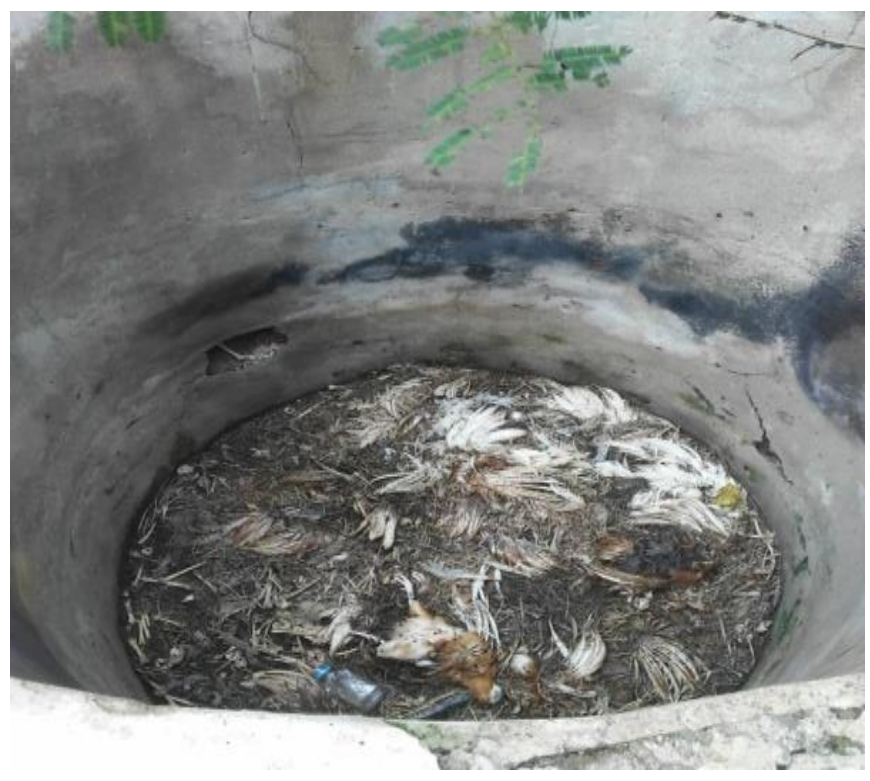

Figure 1: Mortality Pit

\section{Geology of the Study Site}

Geologically, the Precambrian basement complex rocks of South-Western Nigeria underlie the study site (Rahaman 1976). The main lithological units identified in this site are migmatite-gneiss and migmatite - gneiss undifferentiated. The geology of the site was classified based on porosity and permeability of various resulting rock debris after weathering. The charnolates weathered into higher permeability sandy clay sand and sand with higher groundwater discharge capacity while quartzites fractured excellently to increase permeability (see figure3).

\section{Methodology \\ 2D Resistivity Tomography Data Acquisition and Processing}

The ABEM Signal Averaging System (SAS) 1000 Terrameter was employed for smooth apparent resistivity inversion to produce $2 \mathrm{D}$ model of the estimated true subsurface resistivity. 


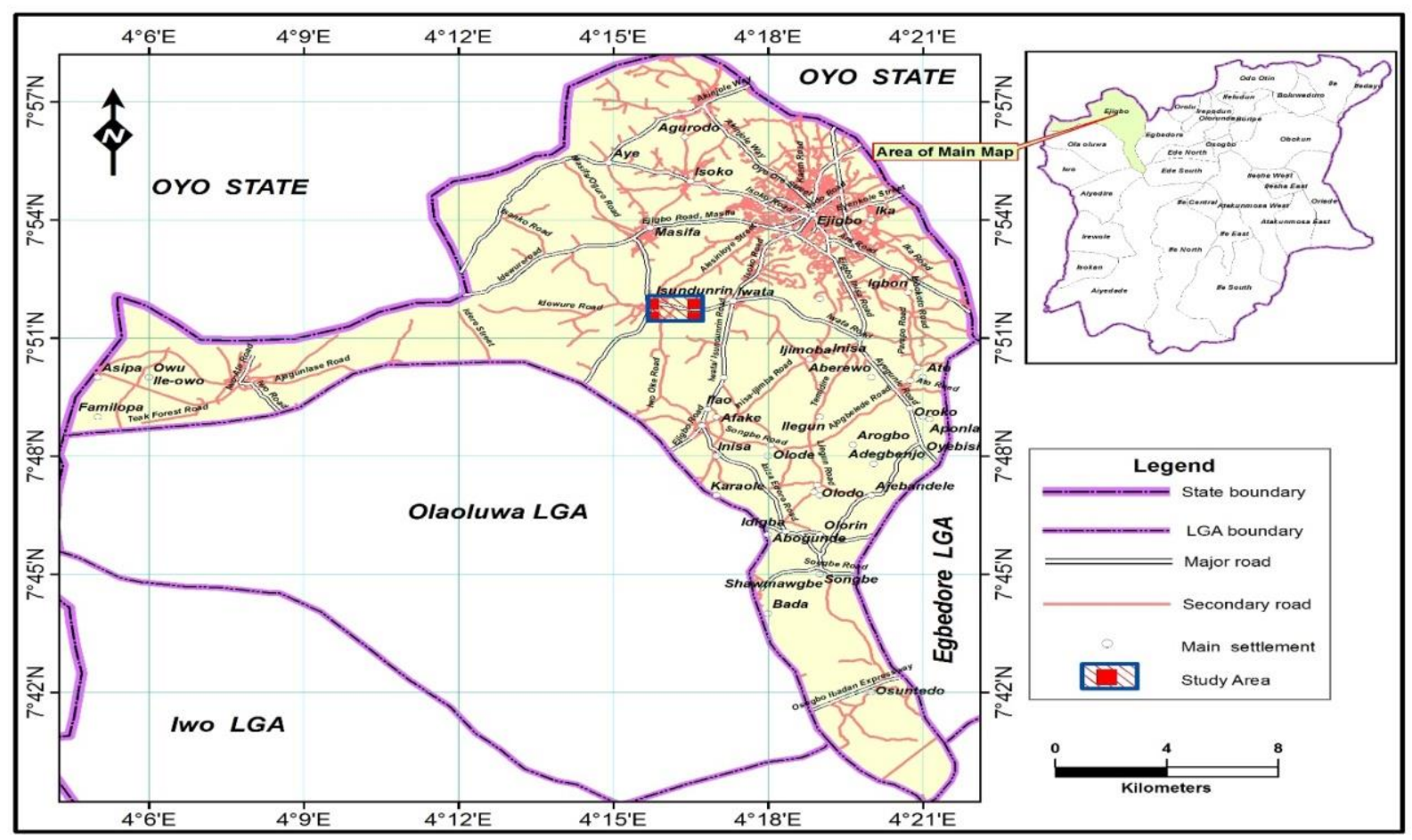

Figure 2: Location Map of the Study Site

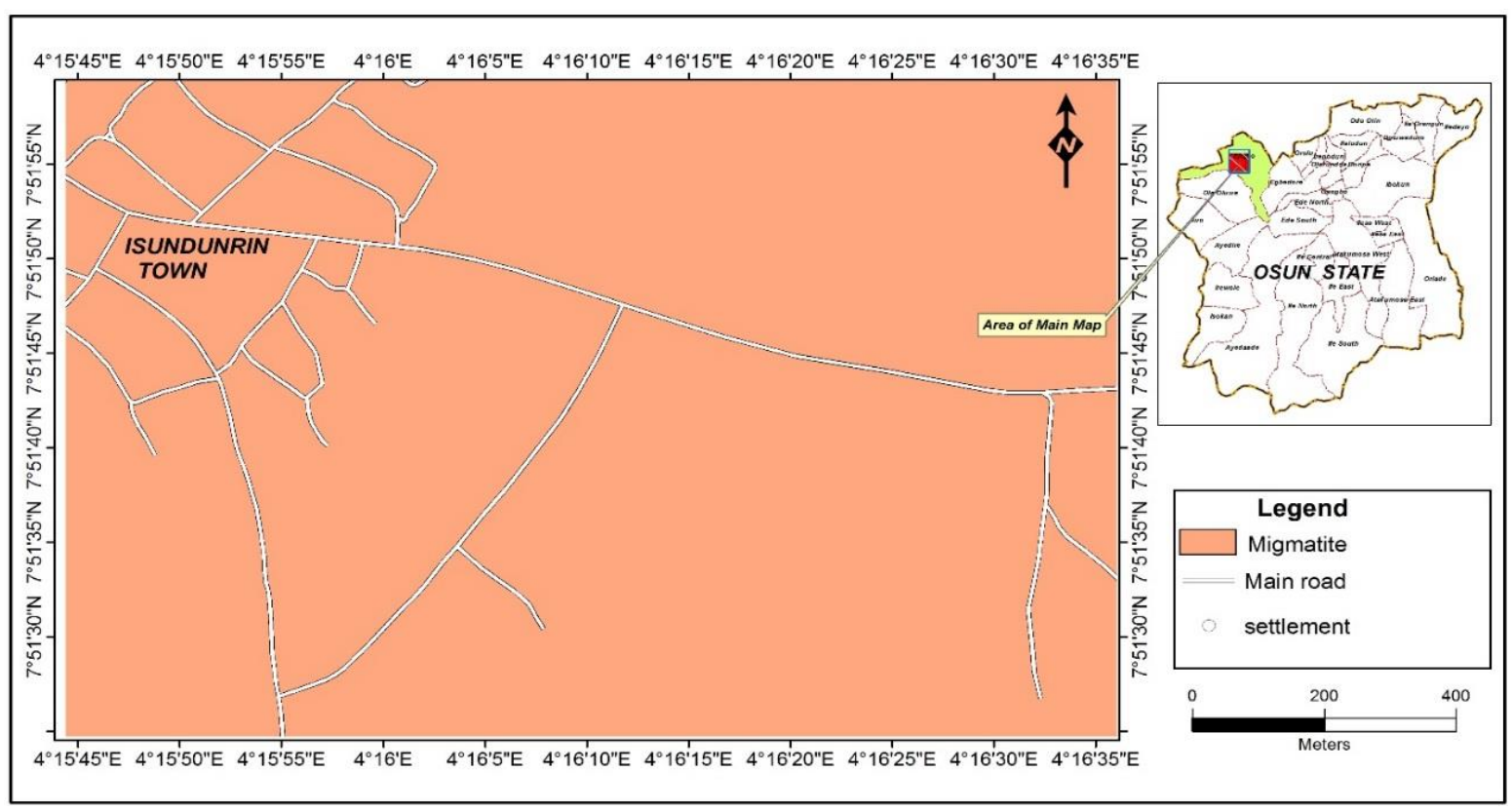

Figure 3: General Geology of Nigeria. (Adapted from Grant, 1970)

This procedure uses Gauss-Newton least squares method (Loke et. al., 2003) based on the initiation of a finite element model of the underground surface. Field forms for collecting dipole-dipole data. In 2D electrical tomography an array of regularly - spaced electrodes were deployed. The common array used is dipole-dipole. In dipoledipole, the spacing between the current electrode pair AB is "a" which is the same as the distance between the potential electrodes pair MN. The 
same process is repeated for measurements with different spacing (' $2 \mathrm{a}$ ' to 'na'). The apparent resistivity $\rho_{a}$ is calculated using:

$\rho_{a}=\pi \alpha R n(n+1)(n+2)$

Where $\mathrm{a}=$ distance between adjacent electrode positions

$\mathrm{n}=$ the number of intervals between the nearest current electrodes to its nearest potential electrodes and the Geometric Factor:

$\mathrm{K}=\pi \alpha n(n+1)(n+2)$

Pomposiello et al., (2012) opine that the median depth of investigation of this array depends upon "n:" factor as well as "a". In this study 2D electrical resistivity tomography were conducted along three profiles. Two of which were very close to the two available mortality pits while the third was conducted $300.0 \mathrm{~m}$ away from the mortality pit as shown in table 1 . The profile length was $100.0 \mathrm{~m}$ and interspaced by $5.0 \mathrm{~m}$ each and oriented in the North-East (Profile1), South-East (Profile 2) and North-East (Profile 3) directions. Measurements were made in sequence of increasing offset distances spacing along the profile lines ranging from $5.0 \mathrm{~m}$ to $100.0 \mathrm{~m}$ using six stainless steel electrodes. The electrodes were moved in a leapfrog manner to achieve continuous horizontal coverage of the subsurface. The data obtained were converted to apparent resistivity, which was later inverted using DIPROWIN modelling software in order to perform 2D geo electrical data inversion. The results obtained from the processing of field data are presented as Resistivity structures, pseudo sections and theoretical pseudo sections from which the relevance of this result used in imaging, the causes of soil, and groundwater contamination in terms of resistivity and conductivity with respect to their depths of occurrence.

\section{Water Samples Collection and Analysis}

Five water samples were collected from five different hand dug wells found within the vicinity of the poultry farm. These samples were taken to the Rural Water and Environmental Sanitation Agency (RUWESA) laboratory for analysis. Depths to static water level of each well, distance from each well to the two disposal pits were measured. The location of each well was taken and recorded with the aid of compass (Table 2).

\section{Results and Discussions Electrical Resistivity Tomography 1}

The 2D resistivity structure along transverse one (Figure 4) shows in the NE direction and $5.0 \mathrm{~m}$ away from the mortality pit 1 , showed a varying resistivity values across this transverse (Figure 4) with some portions being highly resistive, while some parts are of low resistivity (conductive). In this part of the study site, the major subsurface layers delineated are the topsoil $(174-308 \Omega \mathrm{m})$, weathered basement $(424.0-880.0 \Omega \mathrm{m})$ and basement rock $(90330.0 \Omega \mathrm{m})$ which are marked by different colours (Figure 4). The low resistivity values 46.8 to $131.0 \Omega \mathrm{m}$ recorded at points 9,10 , 18 and 20 are indications that the leachate plume had travelled horizontally distances range of 45.0 to $55.0 \mathrm{~m}$ and 80.0 to $100.0 \mathrm{~m}$ at depths greater than $10.0 \mathrm{~m}$ and more than $20.0 \mathrm{~m}$ as shown in figure 4 (the blue and light blue portions). This could be the host of the contaminant resulting from the decomposition of the dead birds since these contaminants migrated from the mortality pit. The resistivity values of the contaminant increased as the contaminant migrated down due to the decrease in density and filtration that had happened. The extent of the contaminant is very prominent at the depth of $5.0 \mathrm{~m}$. The effect of this contaminant was not noticeable at about $15.0 \mathrm{~m}$ at points 9,10 and 11 along the profile length due to the presence of clay soil. The yellow, red and purple portions of the structure are of higher resistivity values ranging from $1350.0 \Omega m$ to $90330.0 \Omega \mathrm{m}$ typical of lateritic material and basement rocks. The thickness of which is about $20.0 \mathrm{~m}$. The lateritic soil and basement protected the study site from further contamination. 
Table 1: Distance of Each Traverse to the Mortality Pit.

\begin{tabular}{ccccc}
\hline S/N & Longitude $\left(^{\circ}\right)$ & Latitude $\left(^{\circ}\right)$ & Distance to Pit 1 $(\mathrm{m})$ & Distance to Pit 2 $(\mathrm{m})$ \\
\hline Traverse 1 & 4.1546 & 7.5152 & 3.00 & 61.30 \\
Traverse 2 & 4.1569 & 7.5156 & 15.30 & 20.30 \\
Traverse 3 & 4.1542 & 7.5152 & 300.00 & 96.40 \\
\hline
\end{tabular}

Table2: Well locations, depth to static water level and their distance to the two Disposal pits.

\begin{tabular}{cccccc}
\hline $\begin{array}{l}\text { Hand dug } \\
\text { Well No }\end{array}$ & $\begin{array}{c}\text { Longitude } \\
\left({ }^{)}\right.\end{array}$ & Latitude $\left({ }^{\circ}\right)$ & $\begin{array}{c}\text { Distance } \\
\text { to pit } 1(\mathrm{~m})\end{array}$ & $\begin{array}{c}\text { Distance } \\
\text { to pit 2 }(\mathrm{m})\end{array}$ & $\begin{array}{c}\text { Depth to Water Table of } \\
\text { well }(\mathrm{m})\end{array}$ \\
\hline Well 1 & 4.1546 & 7.5152 & 39.00 & 61.30 & 7.50 \\
Well 2 & 4.1569 & 7.5156 & 191.30 & 91.30 & 7.44 \\
Well 3 & 4.1542 & 7.5152 & 196.40 & 96.40 & 8.04 \\
Well 4 & 4.1546 & 7.5153 & 189.50 & 89.50 & 7.40 \\
Well 5 & 4.1543 & 7.5156 & 212.70 & 112.70 & 9.80 \\
\hline
\end{tabular}

ISUNDUNRIN 1 (Field Data Pseudosection)

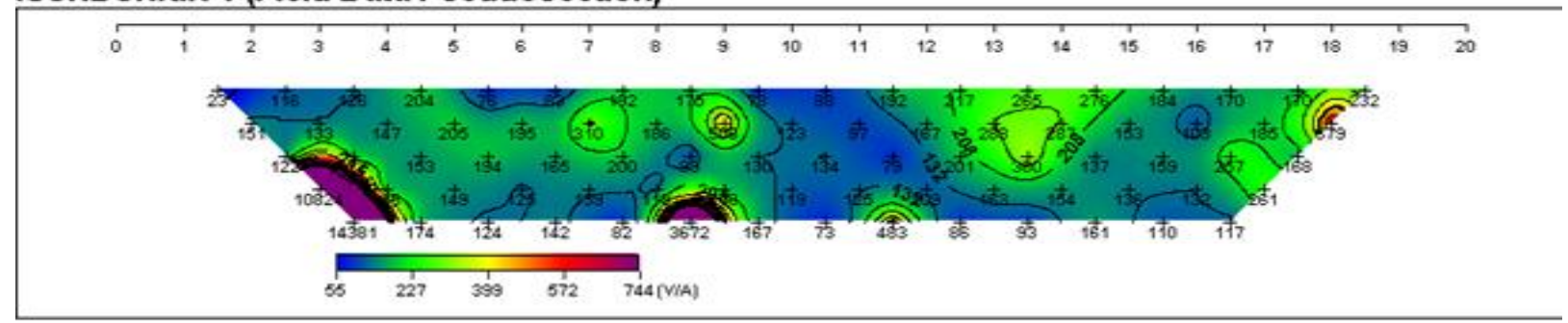

ISUNDUNRIN 1 (Theoretical Data Pseudosection)

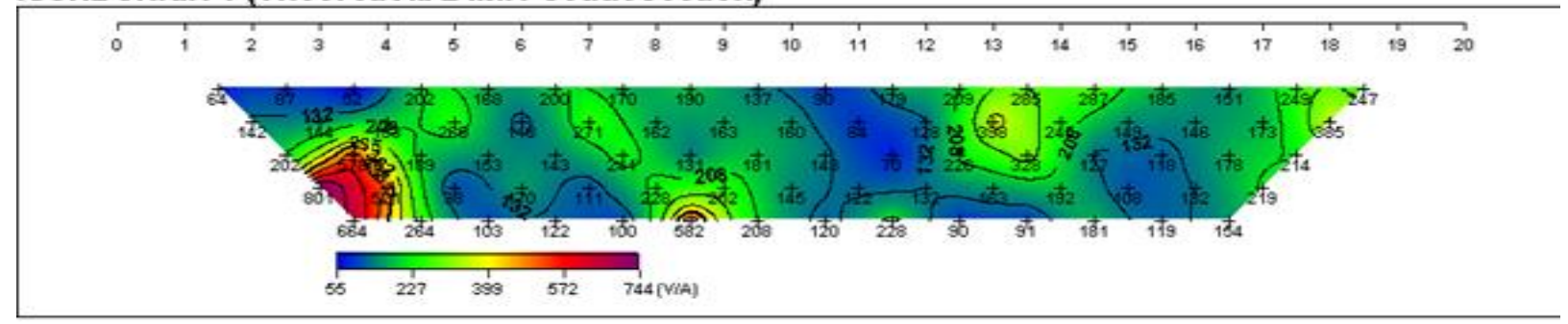

ISUNDUNRIN 1 (2-D Resistivity Structure)

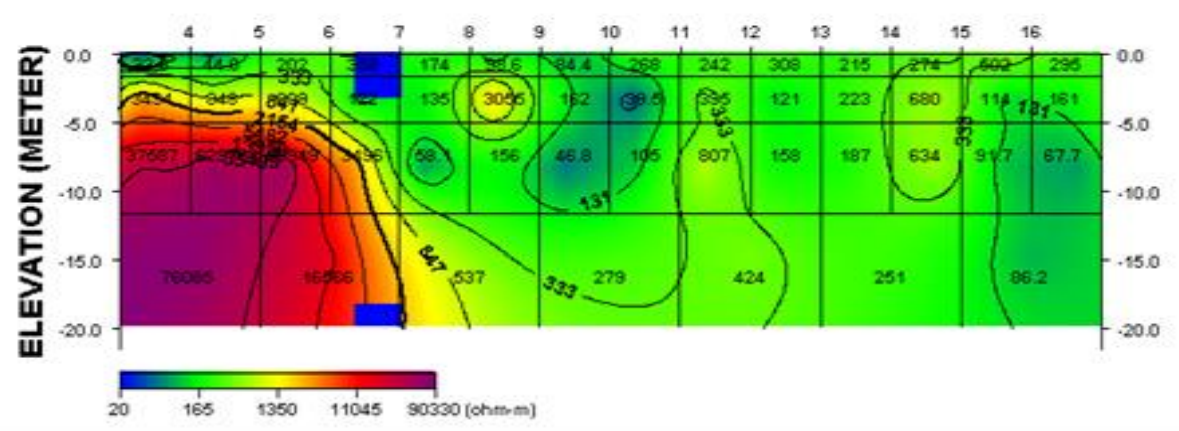

Figure 4: 2D inversion model along traverse 1, $3 \mathrm{~m}$ from Mortality Pit 1

\section{Electrical Resistivity Tomography 2}

Figure 5 shows the 2D resistivity structure along the second profile line/transverse in SW direction also $20.30 \mathrm{~m}$ away from the second mortality pit. In this section of the study site the contaminant host is absent as the resistivity is as low as $126.0 \Omega \mathrm{m}$ to $722.0 \Omega m$ (reddish portion of figure 5) an indication of the presence of lateritic clay soil which may prevent the movement of the generated leachate from pit 2 . The area under investigation 
could be seen as been underlain by clay to a depth of $15.0 \mathrm{~m}$. Below this layer is the basement whose highest resistivity value $4638.0 \Omega \mathrm{m}$ (the purple part of figure 5). The result here indicated that leachate from the mortality pit under investigation is not much and since this pit did not contain enough dead birds since it was abandon long time ago, but now active as reported by the farm manager.

\section{Electrical Resistivity Tomography 3}

The results of the $2 \mathrm{D}$ resistivity along the NE direction, $300.0 \mathrm{~m}$ from mortality Pit 1 is as shown in figure 6 . Low resistivity values ranging from $14.0 \Omega \mathrm{m}$ to $49.0 \Omega \mathrm{m}$ were recorded at more than $12.0 \mathrm{~m}$ depth. These low resistivity values recorded are indications that this portion of the study site is contaminated. The extent of the contamination is prominent at the top most part of the soil and to almost $12.0 \mathrm{~m}$ depth. Beyond this depth, the effect is not noticeable since the resistivity values ( 75 to $198 \Omega \mathrm{m}$ ) were typical of lateritic clay. The lowest resistivity value obtainable at the top is attributable to the contamination from the deposit site of faeces of these birds. This third profile serves as control to the two disposal pits.

\section{Water samples results and Discussion}

The result of the analyses of water samples from five different hand dug wells are shown in Table 3. High values of Total Dissolved Solids (TDS) and conductivities were recorded in the analysis of the water samples from the various wells. These high values of the two water parameters were attributable to the presence of leachate, which originated and had migrated from the dead bird disposal pits to the groundwater. These high values of these two parameters confirmed the low resistivity values recorded when $2 \mathrm{D}$ resistivity Imaging was employed. The presence of high values of these two parameters in Well 4 suggested that the leachate from the disposal pits had migrated beyond the vicinity of the disposal pits. High values of TDS and conductivity recorded in Wells 1 and 2 were due to the closeness of these wells to the two disposal pits.

Well 02 Isundunrin (Field Data Pseudosection)

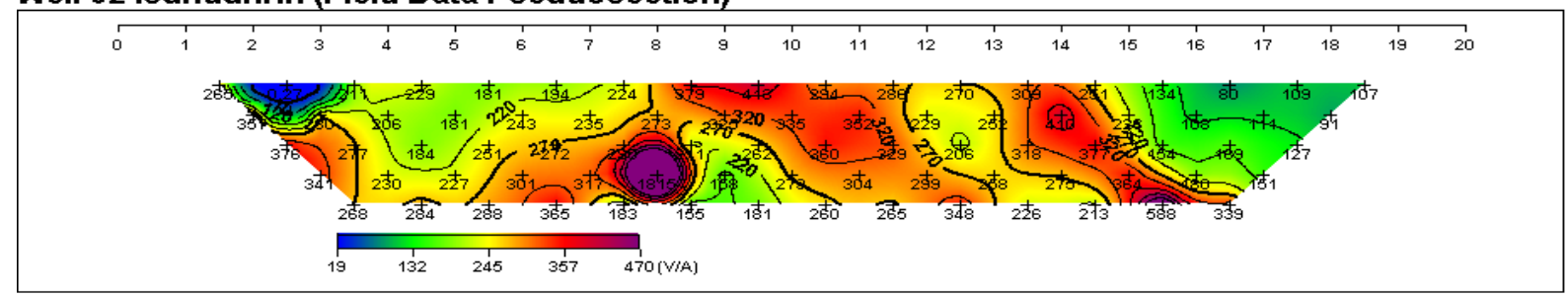

Well 02 Isundunrin (Theoretical Data Pseudosection)

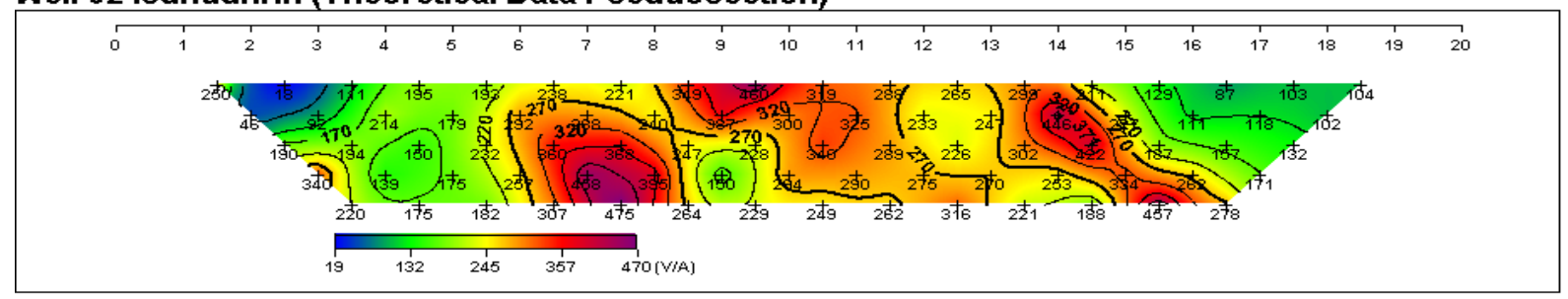

Well 02 Isundunrin (2-D Resistivity Structure)

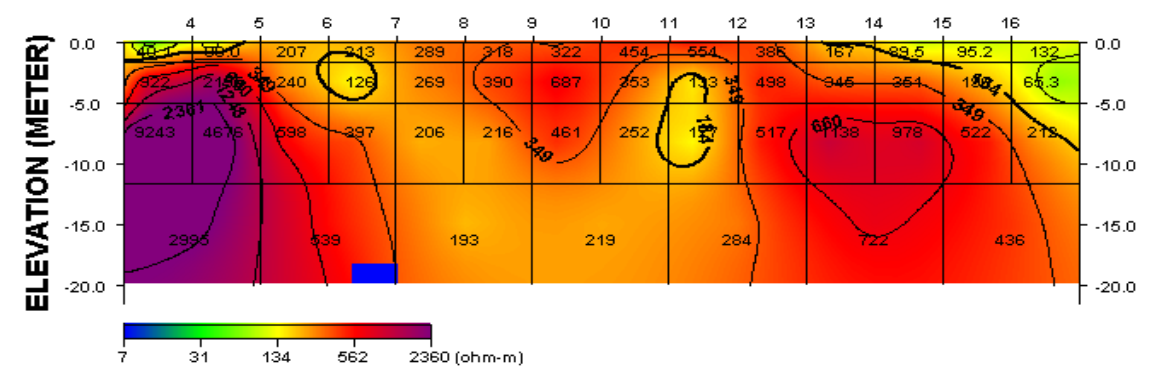

Figure 5: 2D inversion model traverse 2, 20.3m away from Mortality Pit 2 
ISUN FARM FRONT (Field Data Pseudosection)

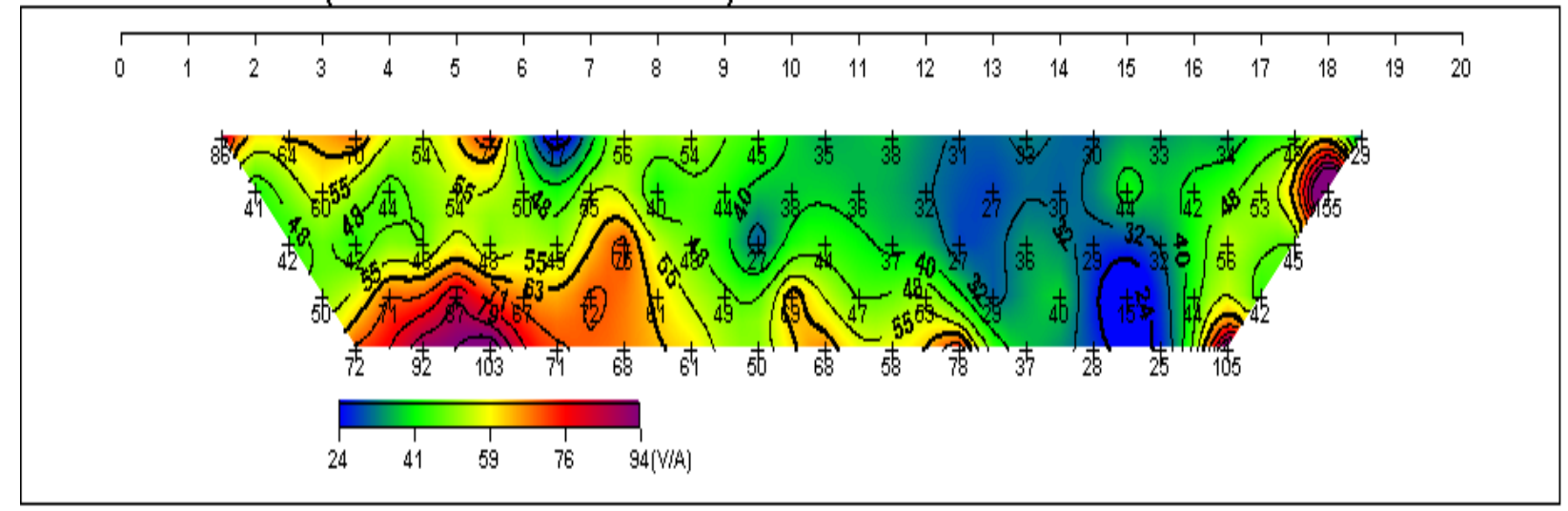

\section{ISUN FARM FRONT (Theoretical Data Pseudosection)}

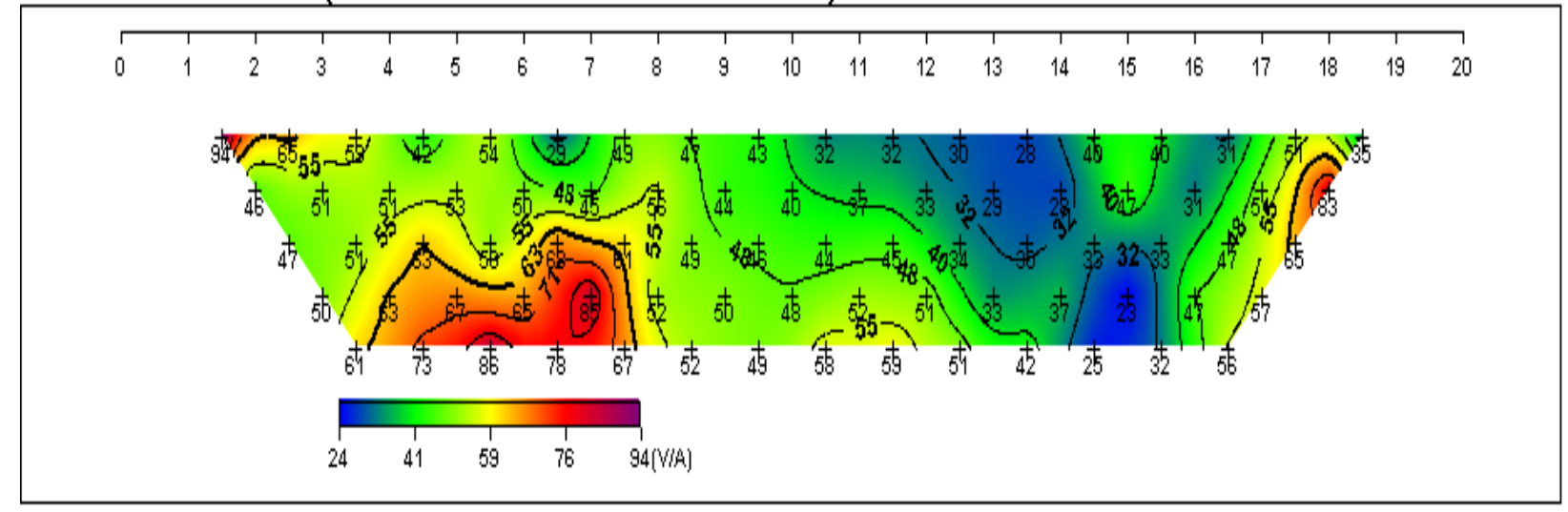

ISUN FARM FRONT (2-D Resistivity Structure)

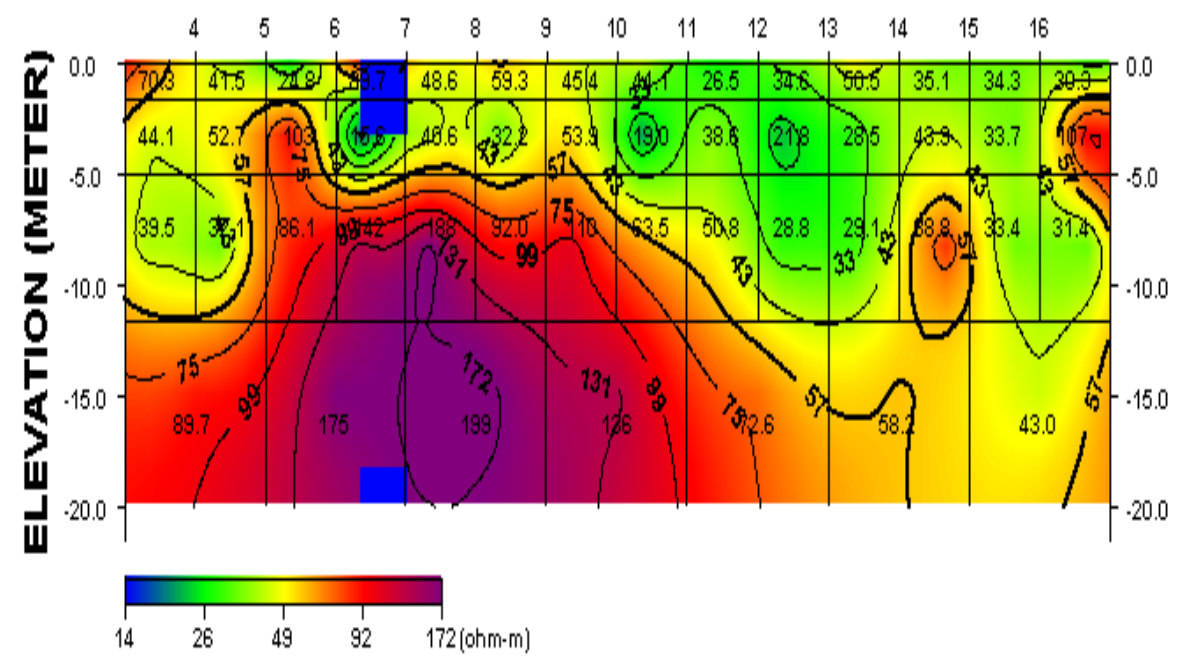

Figure 6: 2D inversion model along traverse 3 (control), $300 \mathrm{~m}$ away from Mortality Pit 1. 
Table 3: Results of hydro-chemical Analyses of the Water Samples

\begin{tabular}{|c|c|c|c|c|c|c|c|}
\hline$S / N$ & Parameter & Well 1 & Well 2 & Well 3 & Well 4 & Well 5 & $\begin{array}{l}\text { WHO } \\
\text { standard } \\
2017 \\
\end{array}$ \\
\hline 1 & Colour (TCU) & Less & Less & Coloured & Less & Less & less \\
\hline 2 & Odour & Less & Less & Odoured & Less & Less & less \\
\hline 3 & Taste & Less & Less & Tasted & Less & Less & Less \\
\hline 4 & Temperature $\left({ }^{\circ} \mathrm{C}\right)$ & 25.300 & 23.400 & 25.400 & 25.400 & 24.100 & 25 \\
\hline 5 & $p H$ & 7.980 & 7.620 & 7.060 & 6.950 & 6.980 & $6.5-8.5$ \\
\hline 6 & O.R.P $(\mathrm{mV})$ & 141.600 & 145.100 & 140.200 & 153.300 & 1550 & \\
\hline 7 & Conductivity $(\mathrm{mg} / \mathrm{l})$ & 0.542 & 0.855 & 0.299 & 0.577 & 0.103 & \\
\hline 8 & T.D.S $(\mathrm{mg} / \mathrm{l})$ & 3650.000 & 5770.000 & 1960.000 & 3890.000 & 690.000 & $600-100$ \\
\hline 9 & Turbidity (NTU) & 1.970 & 3.110 & 6.150 & 2.650 & 2.020 & $1.5-4$ \\
\hline 10 & Chloride (mg/l) & 39.000 & 51.000 & 44.000 & 49.000 & 36.000 & $200-300$ \\
\hline 11 & TotaL Alkalinity $(\mathrm{mg} / \mathrm{l})$ & 10.000 & 06.000 & 08.000 & 04.000 & 08.000 & $200-500$ \\
\hline 12 & Total Hardness $(\mathrm{mg} / \mathrm{l})$ & 270.000 & 92.000 & 138.000 & 82.000 & 92.000 & $200-600$ \\
\hline 13 & Calcium Hardness (mg/l) & 170.000 & 44.000 & 96.000 & 40.000 & 46.000 & $100-300$ \\
\hline 14 & $\begin{array}{l}\text { Magnesium Hardness } \\
(\mathrm{mg} / \mathrm{l})\end{array}$ & 100.000 & 48.000 & 42.000 & 42.000 & 46.000 & $50-100$ \\
\hline 15 & Nitrate $(\mathrm{mg} / \mathrm{l})$ & 0.234 & 0.720 & 3.200 & 0.635 & 7.100 & 50 \\
\hline 16 & Nitrite $(m g / l)$ & 0.044 & 0.007 & 0.095 & 0.016 & 0.027 & 3 \\
\hline 17 & Phosphous (mg/l) & 0.550 & 0.100 & 0.970 & 0.540 & 0.170 & \\
\hline 18 & Amonia $(\mathrm{mg} / \mathrm{l})$ & 0.000 & 0.010 & 0.020 & 0.000 & 0.010 & 35 \\
\hline
\end{tabular}

\section{Conclusion}

In this study, 2D electrical resistivity has been successfully used to identify the extent (depth and lateral) of migration of leachate from poultry mortality pits. It was also used to delineate the various subsurface layers present at the study site. The 2D electrical resistivity imaging delineates resistivity zones to be low. The results obtained showed that the surrounding soil and groundwater were contaminated by the migration of leachate from the mortality pits to a depth of more than 20.0 $\mathrm{m}$. High values of TDS and conductivity recorded in the analysis of water samples in the wells in the vicinity of the disposal pits were evidence that leachate had migrated from these disposal pits to contaminate groundwater and soils. These results were in perfect agreement with the results of the $2 \mathrm{D}$ analysis of traverse 1

\section{References}

Okpoli, C., Oladunjoye, M., Ajayi, T., (2016). Geo electrical assessment of coefficient of permeability and porosity of leachate plume at Asin dumpsite, Iwaro - oka, south western Nigeria. RMZ - AMG 63: 97 - 108 DOI: 10.1515/rmzmag.2016.0009
FAO (2006). World agriculture: towards 2030/2050 interim report. Rome.

Ferket, P.R., van Heugten, E., van Kempen, T.G., and Angel, R. (2002). Nutritional strategies to reduce environmental emissions from non ruminants. J. Anim. Sci. 80 (E.Suppl.2): E168 E182.

Freedman, R., and Fleming, R. (2003). Water quality impacts of burying livestock mortalities. Paper presented to the Livestock Mortality Recycling Project Steering Committee Ridgetown, Canada, Ridgetown college/University of Guelph. (available at http://www.ridgetownc.on.ca/research/documen ts/fleming-caecass burial.pdf).

Ganiyu, S.A., Badmus, B.S., Oladunjoye, M.A., Aizebeokhai, A.P., and Olurin, O.T. (2015). Delination of Leachate plume migration using Electrical resistivity imaging on Lapite dumpsite in Ibadan, South-Western Nigeria. Geosciences, 5(2):70 - 80 DOI:10.5923/j.geo.20150502.03

Gerber, P., Opio, C., and Steinfield, H., (2008). Poultry Production and the Environment - a review. Annual Production and Health Division. Proceeding in Food and Agriculture Organisation of the United Nations $379-405$ 
Grant, N. K. (1970). A computation of radiometric ages from Nigeria. Journal of Mining and Geology: 6: $37-54$.

Hatzell, H. H. (1995). Effect of Waste Disposal Practices on Groundwater at Five Poultry (Broiler) Farms in North - Central Florida, 1992-93. U.S. Geological Survey WaterResources Investigations Report 95 - 4064.

Jegede, S.I., Osazuwa, I.B., Ujuanbi, O., and Chiemeke, C.C., (2011). 2D Electrical imaging survey for situation assessment of leachate plume migration at two waste disposal dumpsites in the Zaria basement complex. Advances in Applied Science Reseach 2 (6): 1 8

Kolominskas, C., Bawden, K., and Ormerod, R., (2002). Strategies to reduce odour emissions from meat chicken farms. Proceeding 2002 Poultry information Exchange 27 - 39 (available at

http://www.fsaconsulting.net/pdfs/PIX\%20Odo ur.PDF)

Loke, M.H., Acworth, I., and Darlin, T., (2003). "A comparison of smooth and blocky inversion methods in 2D electrical imaging surveys:," Geophysics, 35: 266-271,

Myers, L. M., Bush, P. B., Segars, W. I., and Radcliffe, D. E. (1999). Impact of Poultry mortality Pits on Farm Groundwater Quality. Proceedings of the 1999 Georgia Water Resources Conference, held March 30-31, 1999 at the University of Georgia. 234-239

Ogungbe, A.S., Onori, E.O., and Olaoye, M.A.,
(2012). Application of Electrical Resistivity Techniques I the investigation of groundwater contamination: A case study of Ile Epo Dumpsite, Lagos Nigeria International Journal of Geomatics and Geosciences:3 (1) 30 - 40

Pomposiello, C., Dapena,. C., Favetto, A. and Boujon, P. (2012). Application of geophysical methods to waste disposal studies, in Municipal and Industrial Waste Disposal, X.-Y. Yu, Ed.

Rahaman, M. A. (1976). Review of basement Geology of South - western Nigeria, in Geology of Nigeria, edited by Kogbe C. A. 2nd revised edition Elizabethan Publ. Co. Lagos. 41 - 58.

Ritter, W. F., Chirnside, A. E. M., and Harris, J. R. (1988). Impact of dead bird disposal on groundwater quality Paper presented at the International Winter Meeting of the American Society of Agricultural Engineers, Chicago, USA Dec. 3 - 16. Paper No. 88- 2546

Ritter, W. F., and Chirnside, A. E. M. (1995). Impact of dead bird disposal Pits on Groundwater Quality on the Delmarva Peninsula. Bio resource Technology, 53: 105111.

UNDP (2006). Socio - economic impact of avian influenza in Nigeria Abuja. (available at http//www.unnigeria.org/docs/socioecon_ai.pdf.)

WHO (2017). Guidelines for Drinking-Water Quality: Fourth Edition Incorporating the First Addendum. Geneva: World Health Organization; 2017. Available from: https://www.ncbi.nlm.nih.gov/books/NBK4423 $\underline{76 /}$ 